\title{
PEMBELAJARAN DARING DI TENGAH WABAH PANDEMI COVID-19 DI UNIVERSIRTAS ABDURACHMAN SALEH SITUBONDO
}

\author{
Winditiya Yuliana, M.Pd. \\ Universitas Abdurachman Saleh Situbondo \\ Winditiya_yuliana@unars.ac.id
}

\begin{abstract}
Abstrak: Pademi covid-19 yang terjadi di Indonesia telah memperngaruhi dunia pendidikan dalam proses pembelajaran. Tentu diperlukan solusi untuk mengatasi permasalahan tersebut. Pembelajaran secara daring adalah salah satu jalan alternatif yang dapat mengatasi masalah pembelajaran tersebut. Tujuan penelitian ini adalah untuk memperoleh gambaran pelaksanaan pembelajaran daring di Prodi Pendidikan Guru Sekolah Dasar Universitas Abdurachman Saleh Situbondo sebagai upaya menekan penyebaran covid-19 di Perguruan Tinggi. Subjek penelitian pada makalah ini adalah mahasiswa Prodi Pendidikan Guru Sekolah Dasar. Data dikumpulkan dengan cara wawancara melalui google meet. Analisis data dilakukan menggunakan teknik analisis interaktif Miles \& Huberman. Hasil penelitian menunjukkan bahwa: (1) mahasiswa telah memiliki fasilitas dasar yang dibutuhkan untuk mengikuti kegiatan pembelajaran daring; (2) pembelajaran daring memiliki fleksibilitas dalam pelaksanaannya dan mampu mendorong munculnya kemandirian belajar dan motivasi untuk lebih aktif dalam belajar; dan (3) pembelajaran jarak jauh mendorong munculnya perilaku social distancing dan meminimalisir munculnya keramaian mahasiswa sehingga dianggap dapat mengurangi potensi penyebaran Covid-19 di lingkungan perguruan tinggi. Lemahnya pengawasan terhadap mahasiswa, kurang kuatnya sinyal di daerah pelosok, dan mahalnya biaya kuota adalah tantangan tersendiri dalam pembelajaran daring. Meningkatkan kemandirian belajar, minat dan motivasi, keberanian mengemukakan gagasan dan pertanyaan adalah keutungan lain dari pembelajaran daring.
\end{abstract}

Kata kunci: Pembelajaran Online, social distancing, era pandemi Covid-19

\section{PENDAHULUAN}

Wabah corona virus disease 2019 (Covid-19) yang telah melanda 216 negara di dunia, memberikan tantangan tersendiri bagi dunia lembaga pendidikan, khususnya Perguruan Tinggi. Untuk melawan Covid-19 Pemerintah telah melarang untuk berkerumun, pembatasan sosial (social distancing) dan menjaga jarak fisik (physical distancing), memakai masker dan selalu cuci tangan. Melalui Kementerian Pendidikan dan Kebudayaan Pemerintah telah melarang perguruan tinggi untuk melaksanakan perkuliahan tatap muka (konvensional) dan memerintahkan untuk menyelenggarakan perkuliahan atau pembelajaran secara daring (Surat Edaran Kemendikbud Dikti No. 1 tahun 2020). Perguruan tinggi dituntun untuk dapat menyelenggarakan pembelajaran secara daring atau on line (Firman, F., \& Rahayu, S., 2020). 2020).

Tidak sedikit universitas dengan cepat merespon intruksi pemerintah, tidak terkecuali Universitas Indonesia (UI) dengan mengeluarkan surat instruksi tentang pencegahan penyebaran corona virus diesease (Covid-19) di lingkungan Universitas Indonesia. Di surat edaran itu ada 10 poin dan salah satunya adalah anjuran untuk menerapkan pembelajaran daring (Yandwiputra, 2020). Ada sekitar 65 perguruan 
tinggi di Indonesia yang telah melaksanakan pembelajaran daring dalam mengantisipasi penyebaran Covid-19 (CNNIndonesia, 2020). Jamaluddin, D., Ratnasih, T., Gunawan, H., \& Paujiah, E. (2020) menyatakan bahwa pembelajaran daring memiliki kekuatan, tantangan dan hambatan tersendiri.

Untuk mencegah penyebaran Covid-19, WHO memberikan himbauan untuk menghentikan acara-acara yang dapat menyebabkan massa berkerumun. Maka dari itu, pembelajaran tatap muka yang mengumpulkan banyak mahasiswa di dalam kelas ditinjau ulang pelaksanaanya. Perkuliahan harus diselenggarakan dengan skenario yang mampu mencegah berhubungan secara fisik antara mahasiswa dengan dosen maupun mahassiswa dengan mahasiswa (Firman, F., \& Rahayu, S., 2020). Menurut Milman (2015) penggunaan teknologi digital dapat memungkinkan mahasiswa dan dosen melaksanakan proses pembelajaran walaupun mereka ditempat yang berbeda.

Bentuk perkuliahan yang dapat dijadikan solusi dalam masa pandemi covid-19 adalah pembelajaran daring. Menurut Moore, Dickson-Deane, \& Galyen (2011) Pembelajaran daring merupakan pembelajaran yang menggunakan jaringan internet dengan aksesibilitas, konektivitas, fleksibilitas, dan kemampuan untuk memunculkan berbagai jenis interaksi pembelajaran. Penelitian yang dikakukan oleh Zhang et al., (2004) menunjukkan bahwa penggunaan internet dan teknologi multimedia mampu merombak cara penyampaian pengetahuan dan dapat menjadi alternatif pembelajaran yang dilaksanakan dalam kelas tradisional. Pembelajaran daring adalah pembelajaran yang mampu mempertemukan mahasiswa dan dosen untuk melaksanakan interaksi pembelajaran dengan bantuan internet (Kuntarto, E. (2017).

Pada tataran pelaksanaanya pembelajaran daring memerlukan dukungan perangkat-perangkat mobile seperti smarphone atau telepon adroid, laptop, komputer, tablet, dan iphone yang dapat dipergunakan untuk mengakses informasi kapan saja dan dimana saja (Gikas \& Grant, 2013). Perguruan tinggi pada masa WFH perlu melaksanakan penguatan pembelajaran secara daring (Darmalaksana, 2020). Pembelajaran secara daring telah menjadi tuntutan dunia pendidikan sejak beberapa tahun terakhir (He, Xu, \& Kruck, 2014). Pembelajaran daring dibutuhkan dalam pembelajaran di era revolusi industri 4.0 (Pangondian, R. A., Santosa, P. I., \& Nugroho, E., 2019).

Penggunaan teknologi mobile mempunyai sumbangan besar dalam lembaga pendidikan, termasuk di dalamnya adalah pencapaian tujuan pembelajaran jarak jauh (Korucu \& Alkan, 2011). Berbagai media juga dapat digunakan untuk mendukung pelaksanaan pembelajaran secara daring. Misalnya kelas-kelas virtual menggunakan layanan Google Classroom, Edmodo, dan Schoology (Enriquez, 2014; Sicat, 2015; Iftakhar, 2016), dan applikasi pesan instan seperti WhatsApp (So, 2016). Pembelajaran secara daring bahkan dapat dilakukan melalui media social seperti Facebook dan Instagram (Kumar \& Nanda, 2018). Pembelajaran daring menghubungkan peserta didik dengan sumber belajarnya (database, pakar/instruktur, perpustakaan) yang secara fisik terpisah atau bahkan berjauhan namun dapat saling berkomunikasi, berinteraksi atau berkolaborasi (secara langsung/synchronous dan secara tidak langsung/asynchronous). Pembelajaran daring adalah bentuk pembelajaran jarak jauh yang memanfaatkan teknologi telekomunikasi dan informasi, misalnya internet, CD-ROOM (Molinda, 2005). Tujuan dari penelitian ini adalah untuk memperoleh gambaran pembelajaran daring di Program studi Pendidikan Guru Sekolah Dasar Universitas Abdurachman Saleh situbondo di era pandemi covid-19. 


\section{METODE PENELITIAN}

Jenis penelitian yang digunakan adalah penelitian kualitatif. Tujuan penelitian ini adalah menggambarkan pembelajaran daring yang diselenggarakan di Prodi Pendidikan Guru Sekolah Dasar FKIP Universitas Abdurachman Saleh Situbondo sebagai upaya dalam menekan mata rantai penyebaran Covid-19 di lingkungan perguruan tinggi. Pembelajaran daring yang dimaksud dalam penelitian ini adalah pembelajaran yang menggunakan media-media pembelajaran yang dapat diakeses menggunakan layanan internet. Penelitian dilakukan dengan terlebih dahulu mengadakan survey kepada mahasiswa mengenai penerapan pembelajaran daring. Survey disebarkan menggunakan google form yang diberikan kepada mahasiswa melalui pesan WhatsApp. Ada 89 orang subyek yang telah memberikan respon terhadap survei yang disebarkan. Hasil survey kemudian dikelompokkan kedalam tiga kategori respon mahasiswa: (1) Setuju dengan penerapan pembelajaran daring; (2) Tidak setuju dengan penerapan pembelajaran daring; (3) Ragu dengan pelaksanaan pembelajaran daring.

Subjek penelitian adalah mahasiswa Program studi Pendidikan Biologi FKIP Universitas Jambi telah melaksanakan pembelajaran daring, dan dikelompokkan berdasarkan respon subjek penelitian. Di dapatkan 12 orang subjek penelitian, 4 orang mahasiswa angkatan 2017, 4 orang mahasiswa angkatan 2018, dan 4 orang mahasiswa angkatan 2019, 8 orang mahasiswa berjenis kelamin laki-laki dan 4 orang mahasiswa berjenis kelamin perempuan. Pengumpulan data dilakukan melalui wawancara via telpon dan atau zoom cloud meeting. Aspek-aspek yang ditanyakan dalam wawancara adalah: (1) sarana dan prasarana yang dimiliki mahasiswa untuk melaksanakan pembelajaran daring; (2) Respon mahasiswa mengenai efektivitas pembelajaran daring; (3) Pelaksanaan pembelajaran daring dalam memutus mata rantai penyebaran Covid-19 di lingkungan perguruan tinggi. Analisis data penelitian dilakukan menggunakan model analisis Miles \& Huberman (1994) yang terdiri dari tiga tahapan, yaitu reduksi data, display data, serta penarikan dan verifikasi kesimpulan.

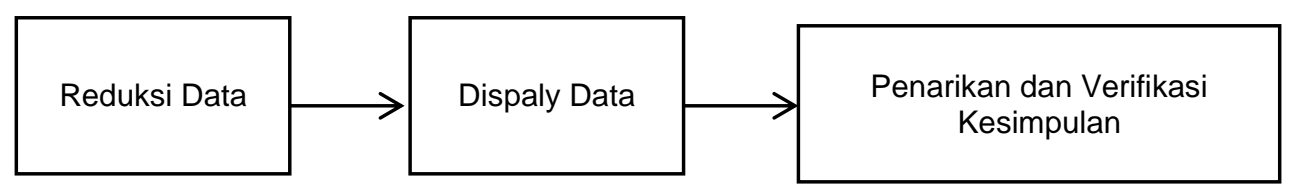

Gambar 1: Tahapan Analisis data penelitian

Analisis data penelitian tahap reduksi data merupakan tahap mengumpulkan seluruh informasi yang dibutuhkan dari hasil wawancara lalu di kelompokkan datanya. Tahap display data merupakan pemaparan data yang diperlukan dalam penelitian dan yang tidak perlu dibuang. Tahap penarikan dan verifikasi kesimpulan adalah tahap interpretasi data penelitian untuk ditarik kesimpulan berdasarkan fenomena yang didapatkan (Miles, M. B., \& Huberman, M.,1994).

\section{HASIL DAN PEMBAHASAN}

\section{Mahasiswa memiliki fasilitas yang memadai untuk melaksanakan pembelajaran daring}

Pemerintah telah memberikan bantuan paket data untuk mendukung proses pembelajaran daring di seluruh Indonesi Guna memutus mata rantai covid-19 yang sampai saat ini angka penyebaran covid-19 masih tetap naik 
setiap harinya khusunya di daerah Situbondo juga masih menunjukkan angka positif confirm covid-19 pada setiap harinya.

Peningkatan dalam penggunaan internet di Indoensia dipengaruhi oleh perkembangan teknologi informasi dan komunikasi (Rahadian, D.,2017). Pada tahun 2018 ada $62,41 \%$ orang penduduk Indonesia telah memiliki telepon seluler dan 20,05 \% rumah tangga telah memiliki komputer dirumahnya (BPS, 2019). Data ini relevan dengan hasil riset yang memaparkan bahwa walaupun ada mahasiswa yang belum memiliki laptop, akan tetapi hampir seluruh mahasiswa telah mempunyai smartphone. Survey yang telah dilakukan melaporkan bahwa 54 orang mempunyai smartphone dan laptop dan 42 orang mempunyai smartphone saja.

Penggunaan smartphone dan laptop dalam pembelajaran daring dapat meningkatkan hasil belajar peserta didik (Anggrawan, A., 2019). Pangondian, R. A., Santosa, P. I., \& Nugroho, E. (2019) menyatakan banyak kelebihan penggunaan teknologi informasi dan komunikasi dalam pelaksanaan pembelajaran daring diantaranya adalah tidak terikat ruang dan waktu.

Penelitian telah banyak dilakukan yang meneliti tentang penggunaan gawa serpti smartphone dan laptop dalam pembelajaran. Kemampuan smartphone dan laptop dalam mengakses internet membantu mahasiswa untuk mengikuti pembelajaran daring (Kay \& Lauricella, 2011; Gikas \& Grant, 2013; Chan, Walker, \& Gleaves, 2015; Gokfearslan, Mumcu, Haßlaman, \& £evik, 2016). Penggunaan pembelajaran daring menggunakan zoom cloud meeting memiliki kelebihan dapat berinteraksi langsung antara mahasiswa dan dosen serta bahan ajar tetapi memiliki kelemahan boros kuata dan kurang efektif apabila lebih dari 20 peserta didik (Naserly, M. K.,2020).

\section{Efektivitas Pembelajaran daring}

Pembelajaran daring yang dilaksanakan di Program Studi Pendidikan Guru Sekolah Dsar Universitas Abdurachman Saleh Situbondo dalam upaya memutus mata rantai penyebaran Covid-19 menggunakan aplikasi SPADA yang telah disiapkan oleh pemerintah untuk menjadi fasilitas pembelajaran daring, pada aplikasi SPADA dosen wajib mengisi RPS (Rencana Pelaksanaan Pembelajaran) mata kuliah yang diampu serta mengaploud PPT (Power point) serta membuat chanel youtube jika diperlukan, perlu diketahui aplikasi SPADA menggunakan email yang telah disediakan Universitas Abdurachman Saleh Situbondo untuk meninjau dan menilai kriteria masing-masing dosen pada saat pembelajran daring dilaksanakan.

Pada kegiatan perkuliahan dengan mahasiswa Prodi Pendidikan Guru Sekolah Dasar Universitas Abdurachman Saleh Situbondo menggunakan aplikasi google meet serta menggunakan aplikasi-aplikasi pembelajaran yang dapat diakses dengan jaringan internet. Secara keseluruhan, mahasiswa puas dengan pembelajaran yang fleksibel. Dengan pembelajaran daring, mahasiswa tidak terkendala waktu dan tempat dimana mereka dapat mengikuti perkuliahan dari rumah masing-masing maupun dari tempat dimana saja. Dengan pembelajaran daring, dosen memberikan perkuliahan melalui kelas-kelas virtual yang dapat diakses dimana pun dan kapan pun tidak terikat ruang dan waktu. Kondisi ini membuat mahasiswa dapat secara bebas memilih mata kuliah yang dikuti dan tugas mana yang harus dikerjakan lebih dahulu. Penelitian Sun et al., (2008) menginformasikan bahwa fleksibilitas waktu, metode pembelajaran, dan tempat dalam pembelajaran daring berpengaruh terhadap kepuasan mahasiswa terhadap pembelajaran.

Ditemukan hasil penelitian yang unik dari penelitian ini yaitu mahasiswa merasa lebih nyaman dalam mengemukakan gagasan dan pertanyaan dalam 
pembelajaran daring. Mengikuti pembelajaran dari rumah membuat mereka tidak merasakan tekanan psikologis dari teman sebaya yang biasa mereka alami ketika mengikuti pembelajaran tatap muka. Ketidakhadiran dosen secara langsung atau fisik juga menyebabkan mahasiswa merasa tidak canggung dalam mengutarakan gagasan. Ketiadaaan penghambat fisik serta batasan ruang dan waktu menyebabkan peserta didik lebih nyaman dalam berkomunikasi (Sun et al., 2008). Lebih lanjut, pembelajaran secara daring menghilangkan rasa cangung yang pada akhirnya membuat mahasiswa menjadi berani berekpresi dalam bertanya dan mengutarakan ide secara bebas.

Pembelajaran daring juga memiliki kelebihan mampu menumbuhkan kemandirian belajar (self regulated learning). Penggunaan aplikasi on line mampu meningkatkan kemandiri belajar (Oknisih, N., \& Suyoto, S., 2019). Kuo et al., (2014) menyatakan bahwa pembelajaran daring lebih bersifat berpusat pada siswa yang menyebabkan mereka mampu memunculkan tanggung jawab dan otonomi dalam belajar (learning autuonomy). Belajar secara daring menuntut mahasiswa mempersiapkan sendiri pembelajarannya, mengevaluasi, mengatur dan secara simultan mempertahankan motiviasi dalam belajar (Sun, 2014; Aina, M.,2016). Sobron, A. N., \& Bayu, R. (2019) menyatakan bahwa pembelajaran daring dapat meningkatkan minat peserta didik.

Pembelajaran daring memiliki tantangan khusus, lokasi mahasiswa dan dosen yang terpisah saat melaksanakan menyebabkan dosen tidak dapat mengawasi secara langsung kegiatan mahasiswa selama proses pembelajaran. Tidak ada jaminan bahwa mahasiswa sunguh-sungguh dalam mendengarkan ulasan dari dosen. Szpunar, Moulton, \& Schacter, (2013) melaporkan dalam penelitiannya bahwa mahasiswa menghayal lebih sering pada perkuliahan daring dibandingkan ketika kuliah tatap muka. Oleh karena itu disarankan pembelajaran daring sebaiknya diselenggarakan dalam waktu tidak lama mengingat mahasiswa sulit mempertahankan konsentrasinya apabila perkuliahan daring dilaksanakan lebih dari satu jam (Khan.,2012).Hasil penelitian juga melaporkan bahwa tidak sedikit mahasiwa yang kesulitan dalam memahami materi perkuliahan yang diberikan secara daring.

Bahan ajar biasa disampaikan dalam bentuk bacaan yang tidak mudah dipahami secara menyeluruh oleh mahasiswa (Sadikin, A., \& Hakim, N., 2019). Mereka berasumsi bahwa materi dan tugas tidak cukup karena perlu penjelasan secara langsung oleh dosen. Garrison \& Cleveland-Innes (2005) dan Swan (2002) melaporkan bahwa kelas yang dosennya sering masuk dan memberikan penjelasan memberikan pembelajaran lebih baik dibandingkan kelas yang dosennya jarang masuk kelas dan memberikan penjelasan.

3. Pembelajaran daring memutus mata rantai Penyebaran Covid-19 di

\section{Perguruan Tinggi}

Pembelajaran daring adalah solusi paling tepat dilakukan para guru dan dosen untuk memutus, mata rantai penyebaran covid 19 dilingkungan perguruan tinggi khususnya Universitas Abdurachman Saleh situbondo, mengingat bahwa Pemerintah telah mendudkung secara langsung yaitu memberikan fasilitas berupa bantuan paket data untuk seluruh guru dan dosen serta siswa dan mahasiswa di seluruh Indonesia, jadi alasan biaya mahal membeli paket data sudah tidak akan menjadi masalah pada pembelajaran daring di era pandemi covid-19

Wabah Covid-19 adalah jenis wabah yang tingkat penyebarannya sangat tinggi dan cepat. Wabah ini menyerang sistem imun dan pernapasan manusia (Rothan \& Byrareddy, 2020). Pencegahan wabah ini dilakukan dengan menghindari interkasi langsung orang yang terinfeksi dengan orang-orang yang 
beresiko terpapar virus corona ini (Caley, Philp, \& McCracken, 2008). Mengatur jarak dan kontak fisik yang berpeluang menyebarkan virus disebut social distancing (Bell et al., 2006).

Berbagai cara telah dilakukan untuk memutus mata rantai penyebaran Covid-19 di lingkungan kampus, Universitas Abdurahchman Saleh Situbondo megingat kemarin salah satu staf sudah ada yang positif confirm terpapar covid 19 ssehingga pembelajran yang telah di desain bertatap muka secara langsung dengan tetap mengikuti protokol kesehatan saat ini kembali menerapkan aturan pembelajaran daring. Perkuliahan dilakukan menggunakan internet sehingga memudahkan dosen dan mahasiswa berinterkasi secara online. Dosen dapat membuat bahan ajar yang dapat diakses oleh mahasiswa dimana saja dan kapan saja. Menurut Bell et al., (2017) pembelajaran daring memungkin adanya interaksi melalui google meet walaupun mereka berada ditempat yang jauh dan berbeda (Arzayeva, et al., 2015). Keberadaan dosen dan mahasiswa yang berada ditempat yang berbeda selama pembelajaran menghilangkan kontak fisik dan mampu mendorong muculnya perilaku social distancing. Menurut Stein (2020) melakukan social distancing sebagai solusi yang baik untuk mencegah penyebaran Covid-19.

Pelaksanaan pembelajaran daring memungkinan mahasiswa dan dosen melaksanakan perkuliahan dari rumah masing-masing. Mahasiswa dapat mengakses materi perkuliahan dan mengirim tugas yang diberikan dosen tanpa harus bertemu secara fisik di kampus. Tindakan ini bisa mengurangi timbulnya kerumunan massa di kampus seperti yang terjadi pada perkuliahan tatap muka. WHO (2020) merekomendasi bahwa menjaga jarak dapat mencegah penularan Covid-19.

Sayangnya, di daerah-daerah yang pelosok seperti mahasiswa yang berasal dari luar pulau (sepudi, raas, dan masalembu) tidak dapat mengakses internet yang baik pelaksanaan pembelajaran daring menunjukkan kecenderungan yang berbeda. Dalam menyiasati kondisi ini, mahasiswa yang tinggal didaerah yang sinyal internet lemah akan mencari wilayah-wilayah tertentu seperti perbukitan dan wilayah kecamatan untuk dapat terjangkau oleh akses internet.

\section{KESIMPULAN}

Dalam rangka memutus mata rantai penyebaran Covid-19 di lingkungan perguruan tinggi, universitas Abdurachman Saleh Situbondo maka Prodi Pendidikan Guru Sekolah Dasar melaksanakan pembelajaran daring sebagai solusi pelaksanaan pembelajaran. Hasil penelitian menunjukkan mahasiswa memiliki sarana dan prasarana untuk melaksanakan pembelajaran daring. Pembelajaran daring efektif untuk mengatasi pembelajaran yang memungkinan dosen dan mahasiswa berinteraksi dalam kelas virual yang dapat diakses dimana saja dan kapan saja.

Pembelajaran daring dapat membuat mahasiswa belajar mandiri dan motivasinya meningkat. Pembelian paket data yang dulu dikeluhkan mahal saat ini sudah tidak lagi menjadi kelmahan pada pembelajaran daring di era pandemi covid-19 dikarenakan Kementrian Pendidikan sudah memberikan bantuan berupa paket data untuk mendukung pembelajaran daring di seluruh Indonesia untuk guru dan dosen serta siswa dan mahasiswa. Jadi pembelajaran daring adalah solusi untuk kegiatan pembelajaran tetap reaktif dan juga dapat memutus mata rantai penyebaran covid 19 dilingkungan Universitas Abdurachman Saleh Situbondo. 
Kelemahan yang ditemukan pada saat penelitian ini dilaksanakan adalah mahasiswa yang berasal dari luar situbondo khususnya dari kepulauan madura seperti sepudi, raas, masa lembu masih susah mencari sinyal pada saat perkuliahan daring dilaksanakan, jadi terkadang mahasiswa tidak dapat mengikuti perkuliahan setiap saat kuliah darig berlangsung. Tetapi kelemahan yang terjadi pada penelitian ini sangatlah sedikit dibandingkan dengan kelebihan dari penelitian ini. Jika di persentasekan kelemahan $20 \%$ dan kelebihan pembelajaran daring adalah $80 \%$.

\section{DAFTAR PUSTAKA}

Arzayeva, M., Rakhimzhanov, K., Abdrahmanova, A., \& Umitkaliev, U. (2015). Special aspects of distance learning in educational system. Anthropologist, 22(3), 449-454. https://doi.org/10.1080/09720073.2015.11891900.

Asif, A. R., \& Rahmadi, F. A. (2017). Hubungan tingkat kecanduan gadget dengan gangguan emosi dan perilaku remaja usia 11-12 tahun (Doctoral dissertation, Faculty of Medicine).

Astuti, P., \& Febrian, F. (2019). Blended Learning Syarah: Bagaimana Penerapan dan Persepsi Mahasiswa. Jurnal Gantang, 4(2), 111-119. https://doi.org/10.31629/ig.v4i2.1560

Bell, D., Nicoll, A., Fukuda, K., Horby, P., Monto, A., Hayden, F., ... Van Tam, J. (2006). Nonpharmaceutical interventions for pandemic influenza, national and community measures Emerging Infectious Diseases. https://doi.org/10.3201/eid1201.051371

Bell, S., Douce, C., Caeiro, S., Teixeira, A., Martin-Aranda, R., \& Otto, D. (2017). Sustainability and distance learning: a diverse European experience? Open Learning, 32(2), 95-102. https://doi.org/10.1080/02680513.2017.1319638

Chan, N. N., Walker, C., \& Gleaves, A. (2015). An exploration of students' lived experiences of using smartphones in diverse learning contexts using a hermeneutic phenomenological approach. Computers and Education. https://doi.org/10.1016Zj.compedu.2014.11.001

Darmalaksana, W. (2020). WhatsApp Kuliah Mobile . Fakultas Ushuluddin UIN Sunan Gunung Djati Bandung.

Enriquez, M. A. S. (2014). Students ' Perceptions on the Effectiveness of the Use of Edmodo as a Supplementary Tool for Learning. DLSU Research Congress. https://doi.org/10.1017/CBO9781107415324.004

Firman, F., \& Rahayu, S. (2020). Pembelajaran Online di Tengah Pandemi Covid-19. Indonesian Journal of Educational Science (IJES), 2(2), 81-89.

Gokfearslan, §., Mumcu, F. K., Haßlaman, T., \& £evik, Y. D. (2016). Modelling smartphone addiction: The role of smartphone usage, self-regulation, general self-efficacy and cyberloafing in university students. Computers in Human Behavior. https://doi.org/10.1016/..chb.2016.05.091

He, W., Xu, G., \& Kruck, S. (2014). Online IS Education for the 21st Century . Journal of Information Systems Education.

Jamaluddin, D., Ratnasih, T., Gunawan, H., \& Paujiah, E. (2020). Pembelajaran daring masa pandemik Covid-19 pada calon guru: hambatan, solusi dan proyeksi. $L P 2 M$.

Iftakhar, S. (2016). GOOGLE CLASSROOM: WHAT WORKS AND HOW? Journal of Education and Social Sciences.

Kay, R. H., \& Lauricella, S. (2011). Exploring the Benefits and Challenges of Using Laptop Computers in Higher Education Classrooms: A Formative Analysis. 
Canadian Journal of Learning and Technology /La Revue Canadienne de I 'apprentissage et de La Technologie. https://doi.org/10.21432/t2s598

Kim, Y., Wang, Y., \& Oh, J. (2016). Digital Media Use and Social Engagement: How Social Media and Smartphone Use Influence Social Activities of College Students. Cyberpsychology, Behavior, and Social Networking. https://doi.org/10.1089/cyber.2015.0408

Korucu, A. T., \& Alkan, A. (2011). Differences between m-learning (mobile learning) and elearning, basic terminology and usage of m-learning in education. Procedia - Social and Behavioral Sciences. https://doi.org/10.1016/i. sbspro.2011.04.029

Siddiqui, S., \& Singh, T. (2016). Social Media its Impact with Positive and Negative Aspects. International Journal of Computer Applications Technology and Research. https://doi.org/10.7753/ijcatr0502.1006

So, S. (2016). Mobile instant messaging support for teaching and learning in higher education. Internet and Higher Education. https://doi.org/10.1016Zj.iheduc.2016.06.001

Stein, R. (2020). COVID-19 and Rationally Layered Social Distancing . International Journal of Clinical Practice. https://doi.org/10.1111/ijcp. 13501

Sobron, A. N., \& Bayu, R. (2019). PERSEPSI SISWA DALAM STUDI PENGARUH DARING LEARNING TERHADAP MINAT BELAJAR IPA. SCAFFOLDING: Jurnal Pendidikan Islam dan Multikulturalisme, 1(2), 30-38.

Sun, P. C., Tsai, R. J., Finger, G., Chen, Y. Y., \& Yeh, D. (2008). What drives a successful eLearning? An empirical investigation of the critical factors influencing learner satisfaction. Computers and Education. https://doi.org/10.1016Zj.compedu.2006.11.007

Swan, K. (2002). Building Learning Communities in Online Courses: the importance of interaction. Education, Communication \& Information. https://doi.org/10.1080/1463631022000005016

Szpunar, K. K., Moulton, S. T., \& Schacter, D. L. (2013). Mind wandering and education: From the classroom to online learning. Frontiers in Psychology. https://doi.org/10.3389/fpsyg.2013.00495

WHO. (n.d.). Points of entry and mass gatherings. Retrieved March 28, 2020, from https://www.who.int/emergencies/diseases/novel-coronavirus-2019/technicalguidance/points-of-entry-and-mass-gatherings

Yandwiputra, A. R. (n.d.). Kuliah Jarak Jauh karena Virus Corona, UI: Bukan Lockdown. Retrieved from https://metro.tempo.co/read/1319537/kuliah-jarakjauh-karena-virus- corona-ui-bukan-lockdown

Zhang, D., Zhao, J. L., Zhou, L., \& Nunamaker, J. F. (2004). Can e-learning replace classroom learning? Communications of the ACM. https://doi.org/10.1145/986213.986216 